\title{
УСТАНОВЛЕНИЕ ЛИЧНОСТИ: СОВРЕМЕННОЕ СОСТОЯНИЕ ПРОБЛЕМЫ ИДЕНТИФИКАЦИИ НЕОПОЗНАННЫХ ТРУПОВ
}

\section{IDENTIFICATION: THE CURRENT STATE OF THE PROBLEM OF IDENTIFICATION OF UNIDENTIFIED CORPSES}

\section{Yakovlev}

Summary. The article discusses the problems of identifying unidentified corpses. The current problems of the organization of identification research are analyzed. An algorithm for establishing the identity of an unidentified corpse by conducting operational search measures and investigative actions, including using modern forensic examination capabilities, is proposed.

Keywords: unidentified corpse, identification, algorithmization of identification studies, operational search measures, investigative actions.

\author{
Яковлев Дмитрий Юрьевич \\ К.ю.н., дочент, Иркутский юридический институт \\ (филиал) Университета прокуратуры \\ Российской Федерации \\ dmitrii-iakovlev@mail.ru
}

Аннотация. В статье обсуждаются проблемы установления личности непознанных трупов. Анализируются актуальные проблемы организации идентификационных исследований. Предлагается алгоритм установления личности неопознанного трупа путем проведения оперативно-розыскных мероприятий и следственных действий, в том числе с использованием современных возможностей судебных экспертиз.

Ключевые слова: неопознанный труп, установления личности, алгоритмизация идентификационных исследований, оперативно-розыскные мероприятия, следственные действия.
B опросы установления личности непознанного трупа находятся под пристальным вниманием научной криминалистической общественности уже не один десяток лет. С момента зарождения криминалистики как науки и до настоящего времени усилия большого числа исследователей направлены на разработку технико-криминалистических приемов и методов, позволяющих идентифицировать труп достоверно, быстро и эффективно. В основном эти усилия направлены на отыскание материальной фиксированной информации, отображающейся на различных предметах материального мира, с которыми человек находился в контакте более или менее продолжительное время.

Несмотря на определенные успехи в теоретическом осмыслении указанной проблемы, на практике отмечается ряд недостатков, носящих систематический характер. Их основа лежит в недостаточно полном выполнении следователями, оперативными работниками, экспертами-криминалистами, судебно-медицинскими экспертами предписанного комплекса следственных и иных действий, направленных на установление личности неопознанного трупа, а также в отсутствие единообразного подхода (алгоритма) осмотра неопознанного трупа [1].

В первую очередь, это связано с нарушением требований основных ведомственных нормативно-правовых актов Министерства внутренних дел, Генеральной прокуратуры Российской Федерации, Следственного комитета России об обязательном присутствии на месте обнаружения неопознанного трупа должностного лица, несущего ответственность за организацию и координацию работы по идентификации трупа. Нередки случаи перепоручения этой работы участковым инспекторам полиции, оперативным сотрудникам уголовного розыска. Зачастую осмотр, в нарушение требований Уголовно-процессуального кодекса, проводится без участия специалистов в области судебной медицины, специалистов-криминалистов.

Анализ уголовных дел, возбужденных по фактам обнаружения неопознанных трупов, позволяет выделить следующие недостатки:

1. Протоколы осмотра места происшествия и осмотра трупа составляются небрежно: по имеющемуся описанию сложно составить представление о состоянии трупа. Элементы и признаки внешности описываются недостаточно полно. Часто при таком описании не используется обязательная криминалистическая терминология, особые и броские приметы описываются с использованием бытовых (разговорных) оборотов речи. Не указывается состоянии одежды, локализация и характер повреждений, обнаруживаемых на трупе, стадия развития трупного явления. Фо- 
тоснимки для фототаблиц выполняются без учета разработанных криминалистической техникой правил и рекомендаций, в том числе, по сигналетической фотосьемке трупа. В случае обнаружения трупа в труднодоступном месте не проводятся повторные осмотры трупа перед проведением судебно-медицинского исследования;

2. крайне редко при осмотре неопознанного трупа применяется видеозапись;

3. сигналетическая фотосъемка проводится после судебно-медицинского исследования трупа, когда большая часть идентификационных признаков утрачена, изменена;

4. при обнаружении трупа с выраженными гнилостными изменениями одежда трупа практически не изымается, а в случае изъятия не хранится должным образом. Имеют место случаи уничтожения одежды в танатологическом отделении бюро судебно-медицинских экспертиз без разрешения следователя, суда;

5. в последнее время перед сигналетической фотосъемкой практически не проводится «туалет трупа»;

6. следователи при вынесении постановления о назначении судебно-медицинской экспертизы трупа ставят на разрешение вопросы не в полном объеме и без учета современных возможностей судебно-медицинской экспертизы;

7. при обнаружении костно-мышечных конгломератов, гнилостно измененных, скелетированных останков не изымаются должным образом черепа, кровь, костная ткань для проведения дальнейших идентификационных, в том числе медико-криминалистических исследований;

8. крайне редко выполняется реконструкция лица по черепу даже случае необходимости проведения идентификационных исследований;

9. игнорируется необходимость дактилоскопирования неопознанного трупа, небрежно составляются дактилоскопические карты.

10. недостаточно полно используются возможности ДНК-анализа для установления личности неопознанных трупов;

11. розыскные дела на неопознанные трупы заводятся несвоевременно с явным опозданием. Кроме того, при их анализе выявляются признаки небрежности в том числе, при заполнении опознавательных карт (в 33\% случаев отсутствует описание элементов внешности, опознавательные фотоснимки);

12. работа по опознанию трупов довольно часто проводится формально без использования оперативных возможностей и данных криминалистических учетов органов внутренних дел. Анализ розыскных дел приводит к выводу о том, что последние со- держат формальный набор версий, которые отрабатываются формально и поверхностно. Не редки случаи, когда поисковые оперативно-розыскные мероприятия проводятся без расширения границ поиска, только в районе обнаружения трупа;

13. в розыскные дела не включаются документы, перечень которых предусмотрен инструкциями МВД России - копии протоколов ОМП, постановлений о назначении судебных экспертиз, справок о местах хранения вещественных доказательств;

14. в недостаточной степени организовывается взаимодействие со средствами массовой информации при установлении личности неопознанного трупа.

На наш взгляд, мощным средством повышения эффективности деятельности по установлению личности непознанных трупов является аналитическая работа, направленная на обобщение положительного опыта идентификации трупов, усиления координации действий различных субъектов идентификации - следователей Следственного комитета РФ, сотрудников уголовного розыска, экспертов криминалистов и судебно-медицинских экспертов, прокуроров, внедрения новых форм и методов работы по установлению личности неопознанных трупов и лиц без вести пропавших.

Однако, несмотря на достигнутые успехи в этой области, установление личности непознанного трупа на сегодняшний день остается серьезной проблемой.

В настоящий момент идентификация трупа осуществляется на основании анатомо-демографических данных при изучении внешней и внутренней морфологии человека с включением в перечень указанных данных и признаков приобретенного характера. При полной или частичной утрате указанных данных применяется целый комплекс следственных действий и оперативно-розыскных мероприятий, в том числе назначение и производство судебных экспертиз. Можно сказать, что задача установления личности решается на основании отождествления обнаруженных и/или выявленных признаков по материально-фиксированным следам отображениям, либо идеальным образом, запечатленным в сознании других людей.

Мы поддерживаем точку зрения В.Е. Корноухова, который отмечает, что важной чертой механизма идентификации неопознанного трупа является комплексность [2, с. 13-41]. При этом под комплексностью следует понимать использование всего спектра современных криминалистических возможностей выявления, фиксации и оценки идентификационных признаков. Однако в последнее время наметилась тенденция необоснованного сужения круга применяемых методик. В частности, практически не используются в идентификации 
признаки зубочелюстного аппарата. Практика идет по пути применения методов генотипоскопического исследования [3]. Следует отметить, что применение таких методов не всегда целесообразно с точки зрения экономичности. Некоторые из возникающих идентификационных задач вполне могут быть решены при использовании традиционных криминалистических методов исследования [4].

По нашему мнению, гораздо эффективнее алгоритмизировать деятельность по установлению личности непознанного трупа, руководствуясь принципом от простого к сложному. При этом, сначала применять традиционные малозатратные методы криминалистического установления личности, переходя на более поздних этапах к применению наукоемких и, как правило, более затратных.

Таким образом, можно говорить о этапности применения различных методов для установления личности.
- На первом этапе допустимо проведение комплекса оперативно-розыскных мероприятий, предусмотренных действующим законом об ОРД. Опрос, отождествление личности, наведение справок, исследование предметов и документов, обследование помещений, зданий, сооружений, участков местности, транспортных средств;

- второй этап предполагает проведение комплекса следственных действий, включающего осмотр места происшествия, осмотр трупа, предъявление для опознания, назначение и производство судебных экспертиз.

Практическое использование предлагаемого алгоритма направлено на повышение эффективности идентификационных исследований при установлении личности, повышению доказательственной значимости получаемых результатов, более детальному выбору объектов и методов идентификационного исследования.

\section{ЛИТЕРАТУРА}

1. Асатрян, Х.А. Современные проблемы идентификации неопознанных трупов / Х.А. Асатрян, Д.О. Эрдынеева. // Молодой ученый.- $2019 .-$ № 28 (266). - C. 95-97.

2. Корноухов, В.Е. Комплексное судебно-экспертное исследование свойств человека / В.Е. Корноухов. — Красноярск: Издательство Красноярского государственного университета, 1982.- - С. 13-41.

3. Перепечина, И.О. Комплексная разработка вопросов судебно-медицинской генетической идентификации: специальность 14.00.24: автореферат диссертации ... доктора медицинских наук / И.0. Перепечина. - Москва, 2005. - 25 с.

4. Токарева, Ю.А. Особенности портретной идентификации по изображениям трупа / Ю.А. Токарева // Энциклопедия судебной экспертизы.— 2021. № $1 .-$ C. 2-3. 